\title{
Immunotargeting in the management of psoriasis
}

\author{
This article was published in the following Dove Press journal: \\ ImmunoTargets and Therapy \\ 29 June 2013 \\ Number of times this article has been viewed
}

\author{
Benjamin H Kaffenberger' \\ Thomas M Kaffenberger ${ }^{2}$ \\ Henry K Wong' \\ 'College of Medicine, Ohio State \\ University, Columbus, OH, USA; \\ ${ }^{2}$ German Cancer Research Center \\ (DKFZ), Heidelberg, Germany
}

\begin{abstract}
The treatment of psoriasis has been revolutionized since the introduction of biologic therapies. Prior to their introduction, it was unclear if psoriasis was primarily a keratinocyte signaling dysfunction or an autoimmune T-cell mediated pathway. Nonspecific T-cell targeting treatments had been used with some success, but they were limited by a narrow therapeutic index. The nonspecific nature of these agents was fraught with side effects, and the efficacy of these treatments pales in comparison to current treatments. The initial biologic molecules, alefacept and efalizumab, were not specific for any T-cell driven pathway, and neither are currently available in the USA. The successors to these early therapies have shown high efficacy and low side effects in psoriasis and other autoimmune diseases through the specific targeting of tumor necrosis factor-alpha (TNF- $\alpha$ ). Since the initial use of antitumor necrosis factor agents, a renaissance in our understanding of psoriasis has been underway, leading to the elucidation of the T-helper 17 (Th17) from the Th1 pathway. With each new treatment, the pathogenesis for psoriasis continues to be more defined, allowing for improved targeted therapies and the ability to achieve new milestones in efficacy.
\end{abstract}

Keywords: psoriasis vulgaris, pathophysiology, immunology, T-cell signaling, biologic therapies, psoriasis treatment

\section{Introduction}

\section{Emerging role of immunotargeting for psoriasis management}

Psoriasis vulgaris is a common skin disease that occurs in up to $1.5 \%-2 \%$ of patients of European descent. ${ }^{1,2}$ It typically presents with thick, erythematous scaly plaques in characteristic locations, including the elbows, knees, umbilicus, genitals, and scalp. Histopathologically, it consists of epidermal regular acanthosis, increased vasculature in the dermal papilla, and thick hyperkeratosis in the stratum corneum with neutrophilladen deposits. It can be generalized and can be present in forms other than the chronic plaque psoriasis, including guttate, palmoplantar, pustular, and inverse patterns. Nail involvement is common with onycholysis, oil drops, and pitting as the most characteristic findings. Beyond the skin, it also may cause destructive arthritis and independently increases the risk of cardiovascular mortality. ${ }^{3}$ The point prevalence of any degree of psoriatic arthritis in a patient survey was around $10 \% .{ }^{4}$ The features of psoriasis are life altering, resulting in a decreased quality of life from itching, arthritis, and disfigurement, which may also result in decreased income potential. ${ }^{5}$ The decreased quality of life, although resulting from alterations limited to the skin and joints, is similar to other chronic illnesses of internal organs. ${ }^{6}$ Further effects, including social 
stigmatization and sexual dysfunction, are significant and have been extensively reviewed. ${ }^{7}$

\section{Genetics of psoriasis}

Psoriasis is a complex multigenic heritable disease. About $30 \%$ of patients with psoriasis will have an affected firstdegree relative. Twin studies have demonstrated a concordance of $35 \%-70 \%$ among monozygotic twins. ${ }^{8,9}$ Based on genetics and clinical presentation, two types of inheritance have been described. Type 1 psoriasis includes patients with familial disease and an early age of involvement. It has been linked to the now-known risk factor $H L A-C w 6 .^{10,11}$ Type 2 has low penetrance. Patients are older when they develop it, and the disease burden is typically less severe. Studies in Type 1 psoriasis indicate that the presence of $H L A-C w 6$, the most highly associated gene among several previously identified as PSORS1, correlated to a 16-fold increased risk of classic young-age psoriasis and a 30-fold increased risk for the development of guttate psoriasis. ${ }^{12}$ Other associations from the human major histocompatibility complex include HLA-B57, while HLA-B40 has a protective effect. ${ }^{13}$ Further studies, including genome-wide association studies (GWAS), which have the potential to evaluate single nucleotide polymorphisms (SNPs), confirmed the association with $H L A-C w 6$, as well as multiple other alleles, including: interleukin (IL)-12; IL-23; and downstream genes associated with tumor necrosis factoralpha (TNF- $\alpha$ ) expression. ${ }^{14}$ IL-12, IL-23, and TNF- $\alpha$ have all become major targets of biologic therapies in psoriasis. Other genetic associations include increased copies of the human $\beta$-defensin gene ${ }^{15}$ and deletions in the late cornified envelope proteins $3 \mathrm{~B}$ and $3 \mathrm{C} .{ }^{16,17}$ Recent analyses have implicated SNPs in a human endogenous retrovirus gene that is located near HLA-C but is independent of HLA-Cw6 as another risk factor. ${ }^{18,19}$

Despite the recent advances in the genetics of psoriasis, there is no simple explanation for the progression from susceptibility to disease. Some environmental risk factors are known, including the development of guttate psoriasis after streptococcal infection, ${ }^{20,21}$ chronic plaque psoriasis flares after streptococcal infection, ${ }^{22}$ improvement in psoriasis in patients with recurrent streptococcal tonsillitis undergoing tonsillectomy, ${ }^{23}$ and psoriasis development after medications that included lithium, beta-adrenergic blockers, and antimalarials. ${ }^{24}$

There is no common mechanism that is universal to different variants of psoriasis; however, it is widely accepted that in susceptible individuals, psoriasis can be caused by a single stimulus, cascading down to an increase in the innate immune system activity level, activation of T-cells, subsequent cytokine secretion, and epidermal proliferation (Figure 1).

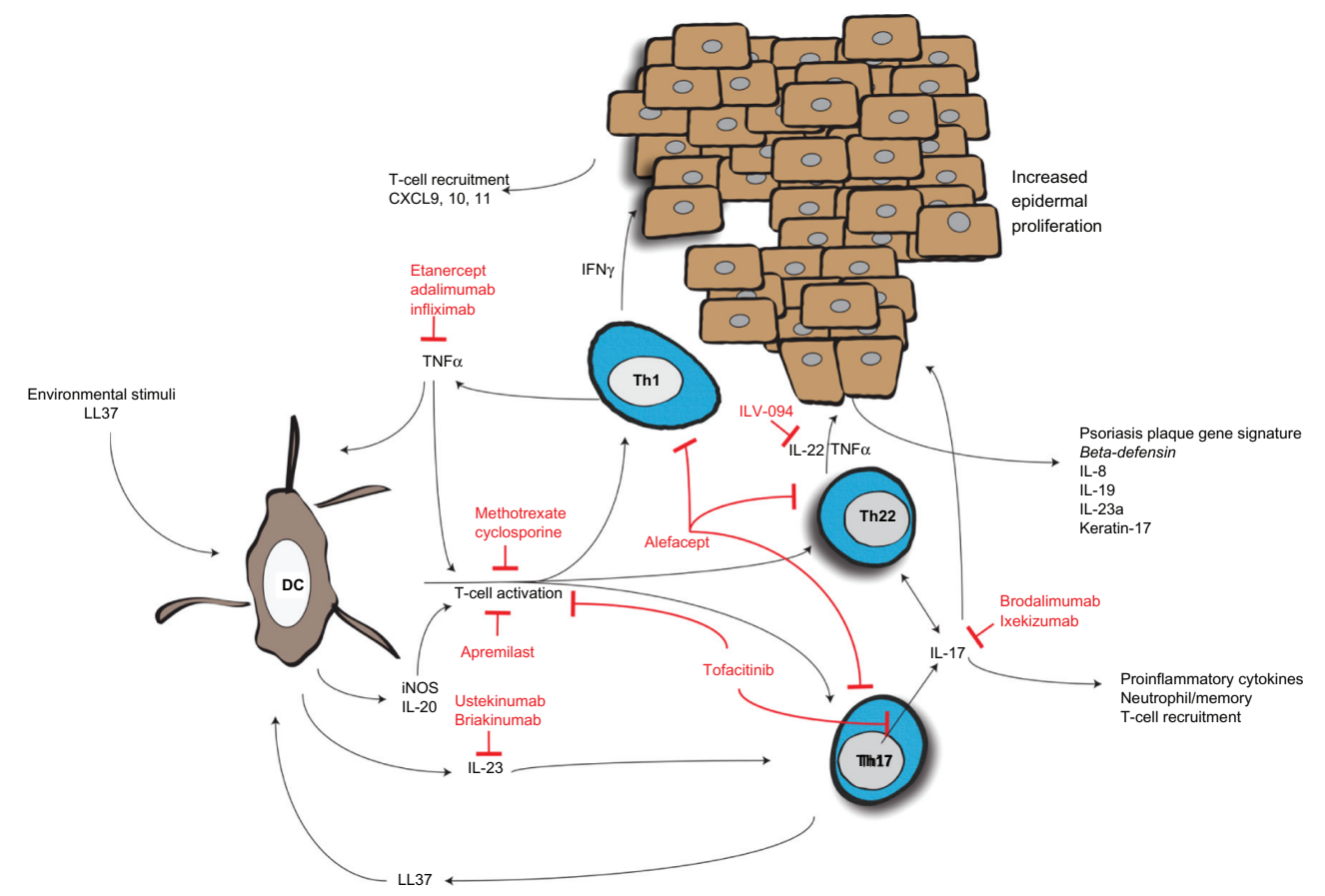

Figure I Activation of dendritic cells and resulting T-cell cytokine milieu results in epidermal acanthosis and proliferation.

Abbreviations: CXCL, chemokine (C-X-C motif) ligand; IFN- $\gamma$, interferon gamma; TNF- $\alpha$, tumor necrosis factor-alpha; iNOS, inducible nitric oxide synthase; IL, interleuken; Th, T-helper; DC, dendritic cells. 


\section{Review of current and emerging immunotargets, and associated pathophysiology}

At one time, it was thought that keratinocytes were the foundation of psoriasis. This has been disproven by genetic studies, ${ }^{10-19}$ as well as results from stem cell transplantation in humans, which showed that psoriasis can be transferred from donors with psoriasis or cured by stem cell transplantation from a nonafflicted donor. ${ }^{25}$ It is unclear how streptococcal and other infections cause the initiation of psoriasis, but it is possible that the peptidoglycan in bacterial cell walls can result in Toll-like receptor-2 (TLR-2) activation and subsequent downstream signaling, or that the initial inflammatory milieu produces autoreactive T-cells that react to human keratin 17, which is upregulated in psoriasis and shares homology to a streptococcal M protein. ${ }^{26}$ TLR-2 is also activated by a gene product of the human endogenous retrovirus $\mathrm{K}$ (HerK) in dendritic cells (DCs), ${ }^{19,27}$ a professional antigen presenting cell, as well as keratinocytes where this receptor appears to be the most concentrated. ${ }^{28} \mathrm{DCs}$, in this case, produce the cytokines after stimulation with the HerK protein dUTPase, which are typical in psoriasis. ${ }^{19}$ This indicates that multiple mechanisms activate DCs to initiate the psoriasis cascade.

The DCs is where the different susceptibility genes and the environmental factors converge. Antimicrobial peptides, such as LL-37, among others, are upregulated in psoriatic plaques, and it has been shown that LL-37 is able to complex with self-RNA and DNA to activate endosomal toll-like receptors (TLR) 7, 8, and 9, which induce DCs to produce interferon- $\alpha($ IFN- $\alpha){ }^{29,30}$

Plasmacytoid DCs (PDC), which normally function as early responders in viral infections, have been found to be highly localized in psoriatic lesional skin. They naturally produce IFN- $\alpha$ and may drive the early T-helper 1 (Th1) cytokine expression early in the development of psoriasis, ${ }^{31}$ and then differentiate into tissue-resident DCs and myeloid DCs (MDC) ${ }^{32}$ TNF- $\alpha$ also plays a role in psoriasis initiation as seen in a mouse model deficient in interferon receptors. ${ }^{33}$ There may be a second population of MDC, now called inflammatory myeloid dendritic cells (iMDC) that express CD11c, but not CD1c, like most tissue resident myeloid cells. ${ }^{34}$ These cells produce inducible nitric oxide synthase (iNOS), IL-20, and IL-23, which are now known to be inhibited early in TNF- $\alpha$ blockage. ${ }^{35-37}$ The levels of IL-23 correlated well with the development of the psoriatic plaque. ${ }^{38}$ A combination of IL-6, and transforming growth factor- $\beta 1$ upregulate the IL-23R on naïve T-cells and allow for differentiation into the Th17 subtype, with IL-23 as a survival factor. ${ }^{39,40} \mathrm{Th} 17$ cells, named for their production of IL-17, and the overall Th17 pathway, now appear to be central to the pathogenesis of psoriasis. IL-17 induces a proinflammatory response, as evidenced by the numerous neutrophils, increased memory T-cells seen in psoriatic lesions. ${ }^{41} \mathrm{TNF}-\alpha$ acts synergistically with IL-17 on the keratinocytes to induce gene expression, specifically elevating human $\beta$-defensin 4 , IL-8, IL-19, and IL-23A, which all characterize psoriasis plaque gene expression signatures. ${ }^{42}$ IL-17 inhibition results in a more extensive downregulation of these synergistic genes than TNF- $\alpha$ inhibition, highlighting the central role of the Th17 cell in the pathogenesis of psoriasis. ${ }^{43}$ IL-17 inhibition blocks upstream genes as well as CD11c dendritic cells, which perhaps is triggered by a positive feedback loop with the LL37/cathelicidin/self-RNA complex that activates the DCs. ${ }^{43}$ Although IL-17 appears to be central to the inflammatory nature, it does not result in acanthosis that typifies psoriasis. Instead, IL-22 secreted from Th17 and Th22 cells acts as the final messenger for epidermal proliferation and dedifferentiation. ${ }^{44-46}$ IL-22 upregulates keratin-17, commonly associated with psoriasis, and does this through a Janus kinase (JAK)/signal transducer and activator of transcription (STAT) mechanism, among others. ${ }^{47}$

\section{Overview of immunotargeted therapies for treatment of psoriasis}

Topical therapies, such as vitamin D analogs, corticosteroids, retinoids, coal tar, and anthralin, will not be reviewed in this article as their effects have already been extensively reviewed. ${ }^{48,49}$

\section{Phototherapy}

Phototherapy in the form of photochemotherapy, psoralen ultraviolet A light (PUVA), broadband ultraviolet B (bbUVB), and narrowband UVB (nbUVB) have long been stalwarts in the treatment of psoriasis. Despite their decades of use, the mechanisms have never been fully elucidated. Both nbUVB and PUVA have been found to decrease costimulatory expression molecules and antigen expression of human major histocompatibility complex in the dermis in psoriatic plaques..$^{50}$ Furthermore, light therapy depletes T-cells in the epidermis via apoptosis and has an apoptotic effect on proliferating keratinocytes. ${ }^{51,52}$ Further studies have shown a strong correlation of nbUVB reduction in dermal dendritic cells $\mathrm{CD} 11 \mathrm{c}+, \mathrm{CD} 1 \mathrm{c}-$, and resolution of psoriasis plaques. ${ }^{53}$ The same study found a significant reduction in downstream cytokines in normalized psoriasis after nbUVB, including IFN- $\gamma$, IL-17, and IL-22. ${ }^{53}$ PUVA may act by 
contributing to an increase in the number of regulatory T-cells (Tregs), functionality of Tregs, and decreasing circulating Th17 cells in some patients. ${ }^{54}$ Clinically, both PUVA and nbUVB, which are more effective than bbUVB in most types of psoriasis, are highly effective, with about $80 \%$ and $70 \%$, respectively, of treated patients obtaining clearance or marked improvement. ${ }^{55}$

Phototherapy is a highly effective treatment modality utilizing multiple mechanisms to control psoriasis, but it has the disadvantage of being inconvenient for patients and ineffective for psoriatic arthritis, and in the case of PUVA, it may increase the long-term risk of cutaneous carcinogenesis.

\section{Nonspecific T-cell therapies}

Methotrexate is a competitive antagonist of dihydrofolate reductase, which blocks de novo pyrimidine and purine synthesis, resulting in decreased B- and T-cell proliferation. In addition, methotrexate may have an anti-inflammatory effect as well. ${ }^{56}$ Recent studies indicate that the effect of low-dose methotrexate may be more related to blocking T-cell adhesion molecule expression than on limiting the cellular proliferation. ${ }^{57}$ Methotrexate shows varying degrees of effectiveness, typically measured by the Psoriasis Area and Severity Index (PASI), which is used with two common cutoffs, PASI-50 and PASI-75, to describe the percentage of patients that develop a $50 \%$ or $75 \%$ improvement, respectively. In early studies, PASI-75 with $15 \mathrm{mg}$ weekly was seen in $60 \%$ of patients. ${ }^{58}$ However, this has been inconsistent; a similar study, although with a starting dose of $7.5 \mathrm{mg}$ weekly, demonstrated only a $24 \%$ PASI- $75 .{ }^{59}$ Methotrexate has been used as the control in several biologic trials and, typically, is found to have a PASI-75 around 35\%-40\%. ${ }^{60-62}$ Dosing is limited, based on side effects and concern for myelosuppression at higher dose; however, methotrexate still represents an affordable option for many patients with psoriasis.

Cyclosporine is a calcineurin inhibitor, originally developed for suppression of rejection of solid organ transplants. Similar to methotrexate, it is not specific for the psoriasis pathways other than for the inhibition of T-cells. It has been found to be slightly more efficacious than methotrexate and typically more rapid, ${ }^{58,59}$ but its use is limited due to side effects and the development of long-term nephrotoxicity. However, a new small molecule inhibitor, voclosporin or ISA-247, has been found to be effective in psoriasis as well. With improved metabolism compared to cyclosporine, nephrotoxicity will hopefully be less of a concern. ${ }^{63}$
Leflunomide is an inhibitor of dihydroorotate dehydrogenase, a step in the de novo pyrimidine synthesis pathway. It has shown some efficacy in the treatment of psoriasis, although more so in psoriatic arthritis, with about $17 \%$ of patients reaching PASI-75. ${ }^{64,65}$ Notably, the prospective study included patients with a lower initial degree of involvement than many others focusing on skin psoriasis. In similar medications, other purine and pyrimidine synthesis inhibitors, such as mycophenolate mofetil, have been trialed with some efficacy, although less than methotrexate. ${ }^{66}$ Chemotherapies, such as hydroxyurea and 6-mercaptopurine, that target the T-cells have been found to be highly effective for the treatment of psoriasis, but as they are only used rarely and their mechanism is not specific, they will not be reviewed.

\section{Phosphodiesterase-4 inhibitors}

Apremilast, an oral small molecule phosphodiesterase-4 inhibitor, is in late-stage trials for psoriasis and psoriatic arthritis. Phosphodiesterase- 4 is the primary phosphodiesterase of mammalian immune cells and results in increased levels of the cyclic adenosine monophosphate (AMP) molecule and inhibition of active cells, blocking TNF- $\alpha$, IL-12, IL-23, and increasing inhibitory IL-10 production. ${ }^{67}$ In early trials, it has shown efficacy in psoriatic arthritis and psoriasis, although PASI-75 scores have ranged from $20 \%-40 \%$ in effective doses from Phase II studies. ${ }^{68-70}$

\section{JAK inhibitors}

Another new class of oral small-molecule inhibitors and topical therapies target the JAK/STAT stimulation pathway. This pathway has been found to be active in cytokine production, common in psoriasis and other autoinflammatory diseases.

Tofacitinib inhibits JAK3/JAK1 signaling for multiple cytokines important in psoriasis, including IL-6 and IL-17. ${ }^{71}$ Tofacitinib was found to be highly effective and well tolerated in Phase II dose studies, with about $66 \%$ of patients achieving PASI-75 improvement at the highest dose. ${ }^{73}$ Health-related quality of life was also improved rapidly in these patients. ${ }^{74}$ Tofacitinib is being developed in a topical formulation that also appears effective. ${ }^{75}$ A topical formulation of a JAK1/ JAK2 inhibitor with a similar mechanism is also under development and has shown promising early results. ${ }^{76}$

\section{Retinoic acid receptor agonists}

Acitretin and formerly etretinate (no longer available in the USA) work through the novel retinoid acid receptors. These receptors are part of the steroid hormone receptor family of transcription factors. They result in a decrease in inflammation 
and an increase in cellular differentiation. ${ }^{77}$ Acitretin is the only systemic agent that treats psoriasis and is not an immunosuppressant, making it an ideal option in patients with human immunodeficiency virus (HIV) and other immunodeficiencies. ${ }^{78}$ It has been shown to have no effect on the Th17 or Th22 pathways. $^{79}$ Its efficacy is frequently limited by side effects; and at doses of 25-50 mg daily, it is not as effective as methotrexate. In fact, it was not even evaluated with PASI-75 in the early trials. ${ }^{80-82}$ The greatest benefit appears to be in a combination of acitretin and phototherapy. Acitretin, combined with UVB, produced a PASI-75 in $60 \%$ of participants $;{ }^{83}$ while in combination with PUVA, it produced a PASI-90 improvement in $96 \%$ of patients. ${ }^{84}$ Acitretin also shows good activity in psoriatic nail disease. ${ }^{85}$

\section{Targeted biologics for T-cells}

Efalizumab is a humanized monoclonal immunoglobulin (Ig) G1 antibody to lymphocyte functional associated antigen-1 (LFA-1) and, specifically, the CD11, which is a subunit of LFA-1. This targets T-cell activation and migration via interactions with endothelial intercellular adhesion molecule-1. Efalizumab was found to increase circulating levels of T-cells, with a concomitant decrease in tissue-infiltrating T-cells within psoriasis plaques. ${ }^{86}$ Downregulation of CD11a on T-cells also leads to the development of anergy that is responsive to drug withdrawal. ${ }^{87}$ It was initially well tolerated in short-term studies and demonstrated PASI-75 rates of $22 \%-30 \%{ }^{88,89}$ The 3-year data appeared to show that the medication was relatively safe and well tolerated, with only mild side effects, such as thrombocytopenia, increase in upper respiratory tract infections, and new onset psoriatic arthritis. ${ }^{90}$ However, this medication was withdrawn from the market in 2009 as multiple cases of progressive multifocal leukoencephalopathy (PML) developed in patients on this medication longer than 3 years. Although both T-cell anergy and inhibition of migration may be the cause of reactivation of the John Cunningham virus, ${ }^{91}$ migration impairment may be more likely based on a similar humanized monoclonal antibody for multiple sclerosis and Crohn's disease that inhibits lymphocyte migration using $\alpha-4$ integrin, natalizumab, in which more than 200 cases of PML have been reported. ${ }^{92}$

Alefacept is a fusion protein of IgG1, combined with lymphocyte function-associated antigen 3 (LFA3), which binds to the cluster of differentiation 2 (CD2) on activated memory T-cells. LFA3 is typically expressed on antigen-presenting cells to produce a mitogenic signal via CD2 activation. Blockage creates a depletion of peripheral effector memory T-cells, which selectively express more CD2 with a relative preservation of central memory and naïve T-cells. ${ }^{93}$ Alefacept differs from other biologic therapies in that the dosing is not continuous and typically requires weekly injections for 12 weeks and then 12 weeks off before restarting as needed. Initial trials showed about $30 \%$ of patients reaching PASI-75 after the first course of therapy. ${ }^{94,95}$

Furthermore, selective targeting of memory T-cells did not appear to result in abnormalities in delayed type hypersensitivity or humoral immunity. ${ }^{95,96}$ This appeared to be effective and safe in up to five courses of treatment, dosed on an as-needed basis. ${ }^{97}$ Unfortunately, the company stopped promoting and distributing alefacept in 2011, which was unrelated to a safety or product recall.

\section{Anti-TNF- $\alpha$ - etanercept, infliximab, adalimumab}

Three anti-TNF- $\alpha$ biologic molecules have been US Food and Drug Administration (FDA) approved for the treatment of psoriasis. In addition, others exist that may be used offlabel, including golimumab and certolizumab.

Etanercept is a fusion protein, linking TNF- $\alpha$ receptor to IgG1. It was incidentally found to be highly effective in psoriasis and demonstrated very high responses based on PASI-75, up to $40 \%-50 \%$ at 24 weeks in initial studies. ${ }^{98,99}$ This was the first of the anti-TNF- $\alpha$ agents to be approved for psoriasis.

Infliximab is a chimeric monoclonal antibody that is given intravenously (IV), targeting soluble TNF- $\alpha$. It has been found to have the highest and most rapid onset of PASI-75 in trials; about $80 \%$ of patients develop rapid and extensive improvement in their psoriasis. ${ }^{100,101}$ As an infusion molecule and the most efficacious, it is noted to have the highest rate of discontinuation due to serious reactions (infusion reactions) of all the anti-TNF molecules. ${ }^{102}$

Adalimumab is a fully human monoclonal antibody targeting soluble TNF- $\alpha$. It is administered less frequently and achieves a PASI-75 of up to $70 \%$ of patients at the standard dosing of $40 \mathrm{mg}$ every other week. ${ }^{61,103,104}$

Although there are differences in efficacy and design, the underlying mechanism is the same, and they will be discussed in that fashion. All three are effective in psoriatic arthritis. ${ }^{98,105,106}$ Inhibition with anti-TNF- $\alpha$ therapies result in a rapid decrease in IL-1, IL-8, IL-23, and iNOS in psoriatic plaques, followed by a decrease in the CD11c DCs, a decrease in messenger RNA for IL-23, and finally a decrease in T-cell infiltration in the psoriatic plaques. ${ }^{107}$ Further experiments of psoriasis plaques in early involution, 1 month after starting etanercept, noted selective CD11c DCs undergoing 
apoptosis, although no circulating or dermal T-cells were noted to be affected in such fashion. ${ }^{108}$ In the follow-up study, it was found that, although etanercept decreases acute response peptides IL- 1 and IL- 8 in all patients, only the responders developed a decrease in IL-17 to normal levels, indicating that TNF- $\alpha$ is early in the cascade. ${ }^{109}$ This resulted in further studies to examine more specific inhibition within the pathways that lead to psoriasis.

\section{Anti-IL-I 2,-23 - ustekinumab, briakinumab}

The most recent US FDA-approved biologic is ustekinumab. It is a fully human IgG1 against the p40 subunit of IL-12 and IL-23 that potentiates the survival signal for Th17 cells. IL-12 and IL-23 are linked by a common p40 subunit that exists constitutively on naïve T-cells. Depending on survival signals, and then whether IL-23R or IL-12B2 is produced, the T-cell may differentiate into Th1 or Th17 cells. This has become a highly effective treatment for psoriasis with PASI-75 developing in $60 \%-70 \%$ of patients. ${ }^{110-112}$ Furthermore, the 3 -year data indicates that this medication is safe with few cardiovascular events, no increase in salmonella infections, and no favoring of a Th2 response, such as asthma developing based on inhibition of the Th1 cytokine IL-12. ${ }^{113,114}$

Briakinumab is another human monoclonal antibody to the p40 subunit of IL-12 and IL-23. While it too was found to be highly effective in Phase III studies, ${ }^{62,115}$ it has not obtained nor is it currently seeking US FDA approval after seven patients had either a stroke, myocardial infarction, or cardiac death in a separate trial. ${ }^{116}$

Based on the 3-year safety data, it does appear that ustekinumab is relatively safe, with the most concerning side effects being the major cardiovascular events occurring in 0.3-0.6 per 100 life years, which is within the expected population range of such events. ${ }^{117}$

\section{Anti-IL-I 7 - brodalumab, ixekizumab}

Recent Phase II trials were just completed for the first two IL-17 inhibitors. Mechanistically, these inhibitors cause upstream and downstream inhibition of genes characteristic of psoriasis. ${ }^{43}$ Brodalumab is a human anti-IL-17R monoclonal antibody that demonstrates high efficacy, with PASI-75 rates reaching $70 \%-80 \%$ of patients. ${ }^{118}$ Ixekizumab is a humanized IgG4 monoclonal antibody to IL-17 that also demonstrates efficacy, with about $70 \%-80 \%$ of treated patients reaching PASI-75 in Phase II studies. ${ }^{119}$ Furthermore, ixekizumab appears to be effective for psoriatic arthritis. ${ }^{119}$ Further studies will be needed, especially to ensure safety, as neutropenia may be a concerning side effect of inhibition of IL-17. ${ }^{118}$

\section{Future research}

The field of psoriasis therapies has expanded exponentially with numerous small-molecule inhibitors and biologics, some that target novel pathways such as IL-22, and others that are less specific in targeting T-cell activation in the pipeline. Many of these are in early-stage development and have been published in a recent review. ${ }^{120}$

\section{Implications for enhanced patient care and quality of life}

Options have expanded dramatically for patients suffering from psoriasis since the beginning of the biologic era. Psoriasis clearly has a substantial burden on patients throughout the world. Even in developed countries, it continues to have significant treatment dissatisfaction. . $^{2,5,121}$ The era of research and development of small molecule inhibitors, as well as targeted extracellular biologics, has created profound impact on patients throughout the world. It is worth noting that PASI-75 did not become the accepted marker for psoriasis improvement until the biologics evolved, because of the significant improvement in psoriasis treatment efficacy. However, significant limitations still remain: how to increase accessibility to care, despite the significant cost burden; ${ }^{122}$ how to maximize the time that each biologic is efficacious ${ }^{102}$ prior to formation of clearing antibodies; and how to ensure long-term safety of these medications.

\section{Conclusion and discussion}

The treatment of psoriasis has progressed substantially in the past 10 years. Although many questions remain, especially regarding the initial pathogenesis of psoriasis and the evolutionary advantage of psoriasis, basic details have emerged from targeted inhibition of cytokines. With each new targeted agent, new data becomes available, highlighting new cytokines involved and new cell types. With the significant advances in psoriasis therapy over the past decade, hopefully new targeted therapies will continue to be developed and allow for more safe and efficacious options for patients with psoriasis.

\section{Acknowledgments}

All authors had full access to the data in the study, and take responsibility for the integrity of the data and the accuracy of data analysis. 


\section{Disclosure}

HK Wong reports honoraria from Amgen Inc and is also an investigator for Amgen, Janssen Pharmaceuticals, Abbott Laboratories, and Celgene Corporation. No sponsors participated in this study. The other authors have no conflicts of interest to report.

\section{References}

1. Gelfand JM, Weinstein R, Porter SB, Neimann AL, Berlin JA, Margolis DJ. Prevalence and treatment of psoriasis in the United Kingdom: a population-based study. Arch Dermatol. 2005;141(12):1537-1541.

2. Stern RS, Nijsten T, Feldman SR, Margolis DJ, Rolstad T. Psoriasis is common, carries a substantial burden even when not extensive, and is associated with widespread treatment dissatisfaction. J Invest Dermatol Symp Proc. 2004;9(2):136-139.

3. Gelfand JM, Neimann AL, Shin DB, Wang X, Margolis DJ, Troxel AB. Risk of myocardial infarction in patients with psoriasis. JAMA. 2006;296(14):1735-1741.

4. Gelfand JM, Gladman DD, Mease PJ, et al. Epidemiology of psoriatic arthritis in the population of the United States. J Am Acad Dermatol. 2005;53(4):573.

5. Gelfand JM, Feldman SR, Stern RS, Thomas J, Rolstad T, Margolis DJ. Determinants of quality of life in patients with psoriasis: a study from the US population. J Am Acad Dermatol. 2004;51(5):704-708.

6. Rapp SR, Feldman SR, Exum ML, Fleischer AB Jr, Reboussin DM. Psoriasis causes as much disability as other major medical diseases. J Am Acad Dermatol. 1999;41(3 Pt 1):401-407.

7. Choi J, Koo JY. Quality of life issues in psoriasis. J Am Acad Dermatol. 2003;49(Suppl 2):57-61.

8. Brandrup F, Hauge M, Henningsen K, Eriksen B. Psoriasis in an unselected series of twins. Arch Dermatol. 1978;114(6):874-878.

9. Duffy DL, Spelman LS, Martin NG. Psoriasis in Australian twins. JAm Acad Dermatol. 1993;29(3):428-434.

10. Stuart P, Malick F, Nair RP, et al. Analysis of phenotypic variation in psoriasis as a function of age at onset and family history. Arch Dermatol Res. 2002;294(5):207-213.

11. Nair RP, Stuart PE, Nistor I, et al. Sequence and haplotype analysis supports HLA-C as the psoriasis susceptibility 1 gene. Am J Hum Genet. 2006;78(5):827-851.

12. Mallon E, Newson R, Bunker CB. HLA-Cw6 and the genetic predisposition to psoriasis: a meta-analysis of published serologic studies. J Invest Dermatol. 1999;113(4):693-695.

13. Feng BJ, Sun LD, Soltani-Arabshahi R, et al. Multiple Loci within the major histocompatibility complex confer risk of psoriasis. PLoS Genet. 2009;5(8):e1000606

14. Nair RP, Duffin KC, Helms C, et al. Genome-wide scan reveals association of psoriasis with IL-23 and NF-kappaB pathways. Nat Genet. 2009;41(2):199-204.

15. Hollox EJ, Huffmeier U, Zeeuwen PL, et al. Psoriasis is associated with increased beta-defensin genomic copy number. Nat Genet. 2008;40(1) 23-25.

16. Riveira-Munoz E, He SM, Escaramís G, et al. Meta-analysis confirms the LCE3C_LCE3B deletion as a risk factor for psoriasis in severa ethnic groups and finds interaction with HLA-Cw6.J Invest Dermatol. 2011;131(5):1105-1109.

17. de Cid R, Riveira-Munoz E, Zeeuwen PL, et al. Deletion of the late cornified envelope LCE3B and LCE3C genes as a susceptibility factor for psoriasis. Nat Genet. 2009;41(2):211-215.

18. Lai OY, Chen H, Michaud HA, et al. Protective effect of human endogenous retrovirus K dUTPase variants on psoriasis susceptibility. J Invest Dermatol. 2012;132(7):1833-1840.

19. Ariza ME, Williams MV. A human endogenous retrovirus K dUTPase triggers a TH1, TH17 cytokine response: does it have a role in psoriasis? J Invest Dermatol. 2011;131(12):2419-2427.
20. Whyte H, Baughman R. Acute guttate psoriasis and streptococcal infection. Arch Dermatol. 1964;89:350-356.

21. Telfer NR, Chalmers RJ, Whale K, Colman G. The role of streptococcal infection in the initiation of guttate psoriasis. Arch Dermatol. 1992;128(1):39-42.

22. Gudjonsson JE, Thorarinsson AM, Sigurgeirsson B, Kristinsson KG, Valdimarsson H. Streptococcal throat infections and exacerbation of chronic plaque psoriasis: a prospective study. $\mathrm{Br} J$ Dermatol. 2003;149(3):530-534.

23. Thorleifsdottir RH, Sigurdardottir SL, Sigurgeirsson B, et al Improvement of psoriasis after tonsillectomy is associated with a decrease in the frequency of circulating $T$ cells that recognize streptococcal determinants and homologous skin determinants. J Immunol. 2012;188(10):5160-5165.

24. Abel EA, DiCicco LM, Orenberg EK, Fraki JE, Farber EM. Drugs in exacerbation of psoriasis. J Am Acad Dermatol. 1986;15(5 Pt 1): $1007-1022$.

25. Kaffenberger BH, Wong HK, Jarjour W, Andritsos LA. Remission of psoriasis after allogeneic, but not autologous, hematopoietic stem-cell transplantation. J Am Acad Dermatol. 2013;68(3):489-492.

26. Gudmundsdottir AS, Sigmundsdottir H, Sigurgeirsson B, Good MF, Valdimarsson $\mathrm{H}$, Jonsdottir I. Is an epitope on keratin 17 a major target for autoreactive T lymphocytes in psoriasis? Clin Exper Immunol. 1999;117(3):580-586

27. Ariza ME, Williams MV, Wong HK. Targeting IL-17 in psoriasis: from cutaneous immunobiology to clinical application. Clin Immunol. 2012;146(2):131-139.

28. Baker BS, Ovigne JM, Powles AV, Corcoran S, Fry L. Normal keratinocytes express Toll-like receptors (TLRs) 1, 2, and 5: modulation of TLR expression in chronic plaque psoriasis. Br J Dermatol. 2003;148:670-679.

29. Ganguly D, Chamilos G, Lande R, et al. Self-RNA-antimicrobial peptide complexes activate human dendritic cells through TLR7 and TLR8. J Exp Med. 2009;206(9):1983-1994.

30. Lande R, Gregorio J, Facchinetti V, et al. Plasmacytoid dendritic cells sense self-DNA coupled with antimicrobial peptide. Nature. 2007;449(7162):564-569.

31. Nestle FO, Conrad C, Tun-Kyi A, et al. Plasmacytoid predendritic cells initiate psoriasis through interferon-alpha production. J Exp Med. 2005;202(1):135-143.

32. Blanco P, Palucka AK, Gill M, Pascual V, Banchereau J. Induction of dendritic cell differentiation by IFN-alpha in systemic lupus erythematosus. Science. 2001;294(5546):1540-1543.

33. Boyman O, Hefti HP, Conrad C, Nickoloff BJ, Suter M, Nestle FO. Spontaneous development of psoriasis in a new animal model shows an essential role for resident $\mathrm{T}$ cells and tumor necrosis factor-alpha. J Exp Med. 2004;199(5):731-736.

34. Zaba LC, Krueger JG, Lowes MA. Resident and "inflammatory" dendritic cells in human skin. J Invest Dermatol. 2009;129(2):302-308.

35. Zaba LC, Cardinale I, Gilleaudeau P, et al. Amelioration of epidermal hyperplasia by TNF inhibition is associated with reduced Th17 responses. J Exp Med. 2007;204(13):3183-3194.

36. Lowes MA, Chamian F, Abello MV, et al. Increase in TNF-alpha and inducible nitric oxide synthase-expressing dendritic cells in psoriasis and reduction with efalizumab (anti-CD11a). Pro Natl Acad Sci U SA. 2005;102(52):19057-19062.

37. Chamian F, Lowes MA, Lin SL, et al. Alefacept reduces infiltrating $\mathrm{T}$ cells, activated dendritic cells, and inflammatory genes in psoriasis vulgaris. Pro Natl Acad Sci U S A. 2005;102(6):2075-2080.

38. Tonel $\mathrm{G}$, Conrad $\mathrm{C}$, Laggner $\mathrm{U}$, et al. Cutting edge: A critical functional role for IL-23 in psoriasis. J Immunol. 2010;185(10):5688-5691.

39. Mangan PR, Harrington LE, O'Quinn DB, et al. Transforming growth factor-beta induces development of the $\mathrm{T}(\mathrm{H}) 17$ lineage. Nature. 2006;441(7090):231-234

40. Morishima N, Mizoguchi I, Takeda K, Mizuguchi J, Yoshimoto T. TGF-beta is necessary for induction of IL-23R and Th17 differentiation by IL-6 and IL-23. Biochem Biophys Res Commun. 2009;386(1): $105-110$. 
41. Nograles KE, Zaba LC, Guttman-Yassky E, et al. Th17 cytokines interleukin (IL)-17 and IL-22 modulate distinct inflammatory and keratinocyte-response pathways. Br J Dermatol. 2008;159(5): 1092-1102.

42. Chiricozzi A, Guttman-Yassky E, Suárez-Fariñas M, et al. Integrative responses to IL-17 and TNF- $\alpha$ in human keratinocytes account for key inflammatory pathogenic circuits in psoriasis. J Invest Dermatol. 2011;131(3):677-687.

43. Krueger JG, Fretzin S, Suárez-Fariñas M, et al. IL-17 A is essential for cell activation and inflammatory gene circuits in subjects with psoriasis. J Allergy Clin Immunol. 2012;130(1):145-154.

44. Boniface K, Guignouard E, Pedretti N, et al. A role for T cell-derived interleukin 22 in psoriatic skin inflammation. Clin Exp Immunol. 2007;150(3):407-415.

45. Boniface K, Bernard FX, Garcia M, Gurney AL, Lecron JC, Morel F. IL-22 inhibits epidermal differentiation and induces proinflammatory gene expression and migration of human keratinocytes. J Immunol. 2005;174(6):3695-3702.

46. Wilson NJ, Boniface K, Chan JR, et al. Development, cytokine profile and function of human interleukin 17-producing helper T cells. Nat Immunol. 2007;8(9):950-957.

47. Zhang W, Dang E, Shi X, et al. The pro-inflammatory cytokine IL-22 up-regulates keratin 17 expression in keratinocytes via STAT3 and ERK1/2. PLoS One. 2012;7(7):e40797.

48. Devaux S, Castela A, Archier E, et al. Topical vitamin D analogues alone or in association with topical steroids for psoriasis: a systematic review. J Eur Acad Dermatol Venereol. 2012;26 Suppl 3:52-60.

49. Castela E, Archier E, Devaux S, et al. Topical corticosteroids in plaque psoriasis: a systematic review of efficacy and treatment modalities. J Eur Acad Dermatol Venereol. 2012;26 Suppl 3:36-46.

50. Erkin G, Uğur Y, Gürer CK, et al. Effect of PUVA, narrow-band UVB and cyclosporin on inflammatory cells of the psoriatic plaque. J Cutan Pathol. 2007;34(3):213-219.

51. Krueger JG, Wolfe JT, Nabeya RT, et al. Successful ultraviolet B treatment of psoriasis is accompanied by a reversal of keratinocyte pathology and by selective depletion of intraepidermal T cells. $J$ Exp Med. 1995;182(6):2057-2068.

52. Aufiero BM, Talwar H, Young $\mathrm{C}$, et al. Narrow-band UVB induces apoptosis in human keratinocytes. $J$ Photochem Photobiol B. 2006;82(2): $132-139$.

53. Johnson-Huang LM, Suárez-Fariñas M, Sullivan-Whalen M, Gilleaudeau P, Krueger JG, Lowes MA. Effective narrow-band UVB radiation therapy suppresses the IL-23/IL-17 axis in normalized psoriasis plaques. J Invest Dermatol. 2010;130(11):2654-2663.

54. Furuhashi T, Saito C, Torii K, Nishida E, Yamazaki S, Morita A. Photo(chemo)therapy reduces circulating Th17 cells and restores circulating regulatory T cells in psoriasis. PLoS One. 2013;8(1):e54895.

55. Archier E, Devaux S, Castela E, et al. Efficacy of psoralen UV-A therapy vs narrowband UV-B therapy in chronic plaque psoriasis: a systematic literature review. J Eur Acad Dermatol Venereol. 2012;26 Suppl 3: $11-21$.

56. Chan ES, Cronstein BN. Molecular action of methotrexate in inflammatory diseases. Arthritis Res. 2002;4(4):266-273.

57. Johnston A, Gudjonsson JE, Sigmundsdottir H, Ludviksson BR, Valdimarsson $\mathrm{H}$. The anti-inflammatory action of methotrexate is not mediated by lymphocyte apoptosis, but by the suppression of activation and adhesion molecules. Clin Immunol. 2005;114(2):154-163.

58. Heydendael VM, Spuls PI, Opmeer BC, et al. Methotrexate versus cyclosporine in moderate-to-severe chronic plaque psoriasis. $N$ Engl $J$ Med. 2003;349(7):658-665.

59. Flytström I, Stenberg B, Svensson A, Bergbrant IM. Methotrexate vs ciclosporin in psoriasis: effectiveness, quality of life, and safety. A randomized controlled trial. Br J Dermatol. 2008;158(1):116-121.

60. Barker J, Hoffmann M, Wozel G, et al. Efficacy and safety of infliximab vs methotrexate in patients with moderate-to-severe plaque psoriasis: results of an open-label, active-controlled, randomized trial (RESTORE1). Br J Dermatol. 2011;165(5):1109-1117.
61. Saurat JH, Stingl G, Dubertret L, et al. Efficacy and safety results from the randomized controlled comparative study of adalimumab vs methotrexate vs placebo in patients with psoriasis (CHAMPION). Br J Dermatol. 2008;158(3):558-566.

62. Reich K, Langley RG, Papp KA, et al. A 52-week trial comparing briakinumab with methotrexate in patients with psoriasis. $N$ Engl J Med. 2011;365(17):1586-1596.

63. Papp K, Bissonnette R, Rosoph L, et al. Efficacy of ISA247 in plaque psoriasis: a randomised, multicentre, double-blind, placebo-controlled phase III study. Lancet. 2008;371(9621):1337-1342.

64. Kaltwasser JP, Nash P, Gladman D, et al. Efficacy and safety of leflunomide in the treatment of psoriatic arthritis and psoriasis: a multinational, double-blind, randomized, placebo-controlled clinical trial. Arthritis Rheum. 2004;50(6):1939-1950.

65. Tlacuilo-Parra JA, Guevara-Gutiérrez E, Rodríguez-Castellanos MA, Ornelas-Aguirre JM, Barba-Gómez JF, Salazar-Páramo M. Leflunomide in the treatment of psoriasis: results of a phase II open trial. Br J Dermatol. 2004;150(5):970-976.

66. Akhyani M, Chams-Davatchi C, Hemami MR, Fateh S. Efficacy and safety of mycophenolate mofetil vs methotrexate for the treatment of chronic plaque psoriasis. J Eur Acad Dermatol Venereol. 2010;24(12): 1447-1451.

67. Schafer PH, Parton A, Gandhi AK, et al. Apremilast, a cAMP phosphodiesterase-4 inhibitor, demonstrates anti-inflammatory activity in vitro and in a model of psoriasis. Br J Pharmacol. 2010;159(4):842-855.

68. Schett G, Wollenhaupt J, Papp K, et al. Oral apremilast in the treatment of active psoriatic arthritis: results of a multicenter, randomized, double-blind, placebo-controlled study. Arthritis Rheum. 2012;64(10):3156-3167.

69. Papp K, Cather JC, Rosoph L, et al. Efficacy of apremilast in the treatment of moderate to severe psoriasis: a randomised controlled trial. Lancet. 2012;380(9843):738-746.

70. Papp KA, Kaufmann R, Thaçi D, Hu C, Sutherland D, Rohane P. Efficacy and safety of apremilast in subjects with moderate to severe plaque psoriasis: results from a phase II, multicenter, randomized, double-blind, placebo-controlled, parallel-group, dose-comparison study. J Eur Acad Dermatol Venereol. 2013;27(3):e376-e383.

71. Meyer DM, Jesson MI, Li X, et al. Anti-inflammatory activity and neutrophil reductions mediated by the JAK1/JAK3 inhibitor, CP-690,550, in rat adjuvant-induced arthritis. J Inflamm (Lond). 2010;7:41.

72. O'shea JJ. Targeting the Jak/STAT pathway for immunosuppression. Ann Rheum Dis. 2004;63 Suppl 2:ii67-ii71.

73. Papp KA, Menter A, Strober B, et al. Efficacy and safety of tofacitinib, an oral Janus kinase inhibitor, in the treatment of psoriasis: a Phase $2 b$ randomized placebo-controlled dose-ranging study. $\mathrm{Br} J$ Dermatol. 2012;167(3):668-677.

74. Mamolo C, Harness J, Tan H, Menter A. Tofacitinib (CP-690,550), an oral Janus kinase inhibitor, improves patient-reported outcomes in a phase $2 \mathrm{~b}$, randomized, double-blind, placebo-controlled study in patients with moderate-to-severe psoriasis. $J$ Eur Acad Dermatol Venereol. Epub January 7, 2013.

75. Ports WC, Khan S, Lan S, et al. A randomised Phase 2a efficacy and safety trial of the topical Janus Kinase inhibitor tofacitinib in the treatment of chronic plaque psoriasis. Br J Dermatol. Epub February 6, 2013.

76. Punwani N, Scherle P, Flores R, et al. Preliminary clinical activity of a topical JAK1/2 inhibitor in the treatment of psoriasis. $J$ Am Acad Dermatol. 2012;67(4):658-664.

77. Duvic M, Nagpal S, Asano AT, Chandraratna RA. Molecular mechanisms of tazarotene action in psoriasis. J Am Acad Dermatol. 1997;37(2 Pt 3): S18-S24.

78. Buccheri L, Katchen BR, Karter AJ, Cohen SR. Acitretin therapy is effective for psoriasis associated with human immunodeficiency virus infection. Arch Dermatol. 1997;133(6):711-715.

79. Caproni M, Antiga E, Melani L, Volpi W, Del Bianco E, Fabbri P. Serum levels of IL-17 and IL-22 are reduced by etanercept, but not by acitretin, in patients with psoriasis: a randomized-controlled trial. J Clin Immunol. 2009;29(2):210-214. 
80. Murray HE, Anhalt AW, Lessard R, et al. A 12-month treatment of severe psoriasis with acitretin: results of a Canadian open multicenter study. J Am Acad Dermatol. 1991;24(4):598-602.

81. Olsen EA, Weed WW, Meyer CJ, Cobo LM. A double-blind, placebocontrolled trial of acitretin for the treatment of psoriasis. $\mathrm{J} \mathrm{Am} \mathrm{Acad}$ Dermatol. 1989;21(4 Pt 1):681-686.

82. Gollnick H, Bauer R, Brindley C, et al. Acitretin versus etretinate in psoriasis. Clinical and pharmacokinetic results of a German multicenter study. J Am Acad Dermatol. 1988;19(3):458-468.

83. Ruzicka T, Sommerburg C, Braun-Falco O, et al. Efficiency of acitretin in combination with UV-B in the treatment of severe psoriasis. Arch Dermatol. 1990;126(4):482-486.

84. Tanew A, Guggenbichler A, Hönigsmann H, Geiger JM, Fritsch P. Photochemotherapy for severe psoriasis without or in combination with acitretin: a randomized, double-blind comparison study. $\mathrm{J} \mathrm{Am}$ Acad Dermatol. 1991;25(4):682-684.

85. Tosti A, Ricotti C, Romanelli P, Cameli N, Piraccini BM. Evaluation of the efficacy of acitretin therapy for nail psoriasis. Arch Dermatol. 2009;145(3):269-271.

86. Krueger J, Gottlieb A, Miller B, Dedrick R, Garovoy M, Walicke P. Anti-CD11a treatment for psoriasis concurrently increases circulating T-cells and decreases plaque T-cells, consistent with inhibition of cutaneous T-cell. J Invest Dermatol. 2000;115(2):333.

87. Guttman-Yassky E, VugmeysterY, Lowes MA, et al. Blockade of CD11a by efalizumab in psoriasis patients induces a unique state of T-cell hyporesponsiveness. J Invest Dermatol. 2008;128(5):1182-1191.

88. Lebwohl M, Tyring SK, Hamilton TK, et al. A novel targeted T-cell modulator, efalizumab, for plaque psoriasis. $N$ Engl $\mathrm{J} \mathrm{Med}$. 2003;349(21):2004-2013.

89. Gordon KB, Papp KA, Hamilton TK, et al. Efalizumab for patients with moderate to severe plaque psoriasis: a randomized controlled trial. JAMA. 2003;290(23):3073-3080.

90. Leonardi C, Menter A, Hamilton T, Caro I, Xing B, Gottlieb AB. Efalizumab: results of a 3-year continuous dosing study for the longterm control of psoriasis. Br J Dermatol. 2008;158(5):1107-1116.

91. Schwab N, Ulzheimer JC, Fox RJ, et al. Fatal PML associated with efalizumab therapy: insights into integrin $\alpha \mathrm{L} \beta 2$ in JC virus control. Neurology. 2012;78(7):458-467.

92. Bloomgren G, Richman S, Hotermans C, et al. Risk of natalizumabassociated progressive multifocal leukoencephalopathy. $N$ Engl J Med. 2012;366(20):1870-1880.

93. Chamian F, Lin SL, Lee E, et al. Alefacept (anti-CD2) causes a selective reduction in circulating effector memory $\mathrm{T}$ cells (Tem) and relative preservation of central memory $\mathrm{T}$ cells $(\mathrm{Tcm})$ in psoriasis. $J$ Transl Med. 2007;5:27.

94. Lebwohl M, Christophers E, Langley R, et al. An international, randomized, double-blind, placebo-controlled phase 3 trial of intramuscular alefacept in patients with chronic plaque psoriasis. Arch Dermatol. 2003;139(6):719-727.

95. Ellis CN, Krueger GG, Alefacept Clinical Study Group. Treatment of chronic plaque psoriasis by selective targeting of memory effector T lymphocytes. N Engl J Med. 2001;345(4):248-255.

96. Gottlieb AB, Casale TB, Frankel E, et al. CD4+ T-cell-directed antibody responses are maintained in patients with psoriasis receiving alefacept: results of a randomized study. J Amer Acad Dermatol. 2003;49(5):816-825.

97. Roberts JL, Ortonne JP, Tan JK, Jaracz E, Frankel E, Alefacept Clinical Study Group. The safety profile and sustained remission associated with response to multiple courses of intramuscular alefacept for treatment of chronic plaque psoriasis. J Am Acad Dermatol. 2010;62(6): 968-978.

98. Mease PJ, Goffe BS, Metz J, VanderStoep A, Finck B, Burge DJ. Etanercept in the treatment of psoriatic arthritis and psoriasis: a randomised trial. Lancet. 2000;356(9227):385-390.

99. Leonardi CL, Powers JL, Matheson RT, et al. Etanercept as monotherapy in patients with psoriasis. $N$ Engl J Med. 2003;349(21): 2014-2022.
100. Chaudhari U, Romano P, Mulcahy LD, Dooley LT, Baker DG, Gottlieb AB. Efficacy and safety of infliximab monotherapy for plaque-type psoriasis: a randomised trial. Lancet. 2001;357(9271): 1842-1847.

101. Reich K, Nestle FO, Papp K, et al. Infliximab induction and maintenance therapy for moderate-to-severe psoriasis: a phase III, multicentre, double-blind trial. Lancet. 2005;366(9494):1367-1374.

102. Yeung H, Wan J, Van Voorhees AS, et al. Patient-reported reasons for the discontinuation of commonly used treatments for moderate to severe psoriasis. J Am Acad Dermatol. 2013;68(1):64-72.

103. Menter A, Tyring SK, Gordon K, et al. Adalimumab therapy for moderate to severe psoriasis: A randomized, controlled phase III trial. J Am Acad Dermatol. 2008;58(1):106-115.

104. Gordon KB, Langley RG, Leonardi C, et al. Clinical response to adalimumab treatment in patients with moderate to severe psoriasis: double-blind, randomized controlled trial and open-label extension study. J Am Acad Dermatol. 2006;55(4):598-606.

105. Kavanaugh A, Krueger GG, Beutler A, et al. Infliximab maintains a high degree of clinical response in patients with active psoriatic arthritis through 1 year of treatment: results from the IMPACT 2 trial. Ann Rheum Dis. 2007;66(4):498-505.

106. Mease PJ, Gladman DD, Ritchlin CT, et al. Adalimumab for the treatment of patients with moderately to severely active psoriatic arthritis: results of a double-blind, randomized, placebo-controlled trial. Arthritis Rheum. 2005;52(10):3279-3289.

107. Gottlieb AB, Chamian F, Masud S, et al. TNF inhibition rapidly downregulates multiple proinflammatory pathways in psoriasis plaques. J Immunol. 2005;175(4):2721-2729.

108. Malaviya R, Sun Y, Tan JK, et al. Etanercept induces apoptosis of dermal dendritic cells in psoriatic plaques of responding patients. $J \mathrm{Am}$ Acad Dermatol. 2006;55(4):590-597.

109. Zaba LC, Suárez-Fariñas M, Fuentes-Duculan J, et al. Effective treatment of psoriasis with etanercept is linked to suppression of IL-17 signaling, not immediate response TNF genes. J Allergy Clin Immunol. 2009;124(5):1022-1030.

110. Kimball AB, Gordon KB, Fakharzadeh S, et al. Long-term efficacy of ustekinumab in patients with moderate-to-severe psoriasis: results from the PHOENIX 1 trial through up to 3 years. Br J Dermatol. 2012;166(4):861-872.

111. Leonardi CL, Kimball AB, Papp KA, et al. Efficacy and safety of ustekinumab, a human interleukin-12/23 monoclonal antibody, in patients with psoriasis: 76-week results from a randomised, double-blind, placebocontrolled trial (PHOENIX 1). Lancet. 2008;371(9625):1665-1674

112. Papp KA, Langley RG, Lebwohl M, et al. Efficacy and safety of ustekinumab, a human interleukin-12/23 monoclonal antibody, in patients with psoriasis: 52-week results from a randomised, doubleblind, placebo-controlled trial (PHOENIX 2). Lancet. 2008;371(9625): $1675-1684$.

113. Lebwohl M, Leonardi C, Griffiths CE, et al. Long-term safety experience of ustekinumab in patients with moderate-to-severe psoriasis (Part I of II): results from analyses of general safety parameters from pooled Phase 2 and 3 clinical trials. J Am Acad Dermatol. 2012;66(5): 731-741.

114. Gordon KB, Papp KA, Langley RG, et al. Long-term safety experience of ustekinumab in patients with moderate to severe psoriasis (Part II of II): results from analyses of infections and malignancy from pooled phase II and III clinical trials. J Am Acad Dermatol. 2012;66(5): $742-751$.

115. Strober BE, Crowley JJ, Yamauchi PS, Olds M, Williams DA. Efficacy and safety results from a phase III, randomized controlled trial comparing the safety and efficacy of briakinumab with etanercept and placebo in patients with moderate to severe chronic plaque psoriasis. Br J Dermatol. 2011;165(3):661-668.

116. Gordon KB, Langley RG, Gottlieb AB, et al. A phase III, randomized, controlled trial of the fully human IL-12/23 mAb briakinumab in moderate-to-severe psoriasis. J Invest Dermatol. 2011;132(2): 304-314. 
117. Reich K, Langley RG, Lebwohl M, et al. Cardiovascular safety of ustekinumab in patients with moderate to severe psoriasis: results of integrated analyses of data from phase II and III clinical studies. $\mathrm{Br} J$ Dermatol. 2011;164(4):862-872.

118. Papp KA, Leonardi C, Menter A, et al. Brodalumab, an anti-interleukin17-receptor antibody for psoriasis. $N$ Engl J Med. 2012;366(13): 1181-1189.

119. Leonardi C, Matheson R, Zachariae C, et al. Anti-interleukin-17 monoclonal antibody ixekizumab in chronic plaque psoriasis. $N$ Engl J Med. 2012;366(13):1190-1199.
120. Gudjonsson JE, Johnston A, Ellis CN. Novel systemic drugs under investigation for the treatment of psoriasis. $J$ Am Acad Dermatol. 2012;67(1):139-147.

121. Bickers DR, Lim HW, Margolis D, et al. The burden of skin diseases: 2004 a joint project of the American Academy of Dermatology Association and the Society for Investigative Dermatology. $J$ Am Acad Dermatol. 2006;55(3):490-500.

122. Ferrándiz C, García A, Blasco AJ, Lázaro P. Cost-efficacy of adalimumab, etanercept, infliximab, and ustekinumab for moderate-to-severe plaque psoriasis. J Eur Acad Dermatol Venereol. 2012;26(6):768-777.

\section{Publish your work in this journal}

ImmunoTargets and Therapy is an international, peer-reviewed open access journal focusing on the immunological basis of diseases, potential targets for immune based therapy and treatment protocols employed to improve patient management. Basic immunology and physiology of the immune system in health, and disease will be also covered. In addition, the journal will focus on the impact of manage-

\section{Dovepress}

ment programs and new therapeutic agents and protocols on patient perspectives such as quality of life, adherence and satisfaction. The manuscript management system is completely online and includes a very quick and fair peer-review system, which is all easy to use. Visit http://www.dovepress.com/testimonials.php to read real quotes from published authors.

Submit your manuscript here: http://www.dovepress.com/immunotargets-and-therapy-journal 